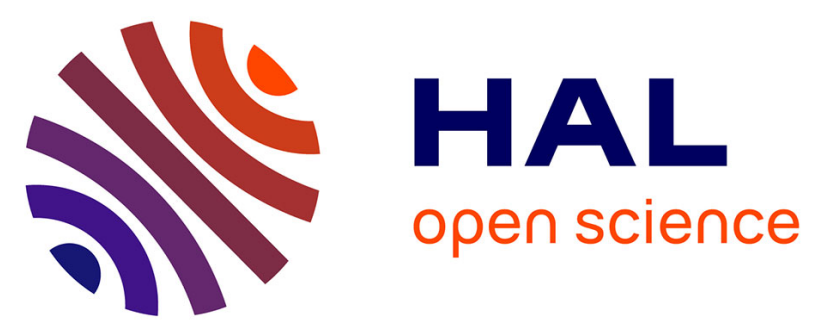

\title{
Balance and dominance in the vocabulary of German-Turkish primary schoolchildren
}

Elke G Montanari, Mehmet-Ali Akinci, Roman Abel

\section{To cite this version:}

Elke G Montanari, Mehmet-Ali Akinci, Roman Abel. Balance and dominance in the vocabulary of German-Turkish primary schoolchildren. European Journal of Applied Linguistics. , 2019, 7 (1), pp.113-143. 10.1515/eujal-2018-0003 . halshs-02360804

\section{HAL Id: halshs-02360804 \\ https://shs.hal.science/halshs-02360804}

Submitted on 15 Nov 2019

HAL is a multi-disciplinary open access archive for the deposit and dissemination of scientific research documents, whether they are published or not. The documents may come from teaching and research institutions in France or abroad, or from public or private research centers.
L'archive ouverte pluridisciplinaire HAL, est destinée au dépôt et à la diffusion de documents scientifiques de niveau recherche, publiés ou non, émanant des établissements d'enseignement et de recherche français ou étrangers, des laboratoires publics ou privés.

$$
\text { Copyright }
$$




\title{
Balance and Dominance dominance in the vocabulary of German-Turkish primary schoolchildren
}

\author{
Elke G. Montanari ${ }^{1}$ \\ Mehmet-Ali Akınci ${ }^{2}$ \\ Roman $\mathrm{Abel}^{3}$
}

\begin{abstract}
Balanced bilingualism has inspired debates on bilingualism for a long time, but several questions related to this discourse remain unanswered. How common are balanced bilinguals? Does balance have a positive impact on language proficiency? More specifically, when children begin to frequent schools and thus have a lot of oral and literal input in the school language, how do balance and dominance develop? The present paper discusses the following research questions with respect to vocabulary: Do balanced test results in two languages correlate with a better proficiency than unbalanced results? Moreover, is a balanced use of two languages accompanied by a balanced vocabulary? We used a picture naming task to test the expressive and receptive vocabulary of 98 German-Turkish speaking schoolchildren in a cross-sectional design. To determine balance or dominance, we used a combined score of the values in the German and the Turkish testing. The balance/dominance scores show a continuous shift to dominance in the majority language. Consistent use of Turkish has an effect on Turkish vocabulary, but not a negative impact on vocabulary in German. There was no overall positive influence of balanced bilingualism.
\end{abstract}

\section{Türkçe özet}

Dengeli ikidillilik, son zamanlarda ikidillilik üzerine gerçekleştirilen birçok çalışmanın araştırma konusu olmuştur, ancak dengeli ikidilliliğin ne denli yaygın olduğu ve dengenin dil becerisi üzerinde olumlu etkisinin olup olmadığı merak konusudur. Özellikle, diller arasındaki denge ve baskınlığın, çocuğun okul dönemine girmesiyle birlikte gerçekleşen sözlü ve yazılı girdi artışından nasıl etkilendiği araştırılmalıdır. Bu makale, sözcük dağarcı̆̆ı kapsamında şu araştırma sorularına yanıt aramaktadır: Her iki dilde de denge saptanan test sonuçlarında, denge saptanmayan test sonuçlarına göre dil becerisi daha mı gelişmiştir? Ayrıca dillerin dengeli kullanımı aynı zamanda her iki dilde de eşit sözcük dağarcığına mı işaret etmektedir? Bu amaçla, 98 AlmancaTürkçe ikidilli ilkokul öğrencisinin konuşma ve anlama becerisini, görsellerin çeşitliliğini de gözeterek, resim adlandırma testiyle inceledik. Diller arasında denge mi baskınlık mı olduğunu saptamak için, Almanca ve Türkçe test sonuçlarının puanlarını birleştirerek değerlendirdik. Denge/baskınlık puanları çoğunluk dilinde sürekli bir değişime işaret etmektedir. Düzenli Türkçe kullanımı Türkçe sözcük dağarcığını olumlu yönde etkilerken, Almanca sözcük dağarcığı üzerinde olumsuz bir etkisi olmamaktadır. Genel olarak bakıldığında dengeli iki

\footnotetext{
${ }^{1}$ Stiftung Universität Hildesheim, Deutschland

${ }^{2}$ Université de Rouen Normandie, France

${ }^{3}$ Universität Kassel, Deutschland
} 
dilliliğin olumlu bir etkisi gözlemlenmemiştir. Eleştirel bir yaklaşım olarak, aynı testin farklı dillerde sözcük dağarcığını ölçmek için kullanılması, bu testin bazı diller için daha uygun olabileceğine dikkat çekmiştir.

\section{Resumen}

El bilingüismo equilibrado ha inspirado los debates sobre el bilingüismo durante mucho tiempo, pero ¿con que frecuencia se puede hablar de bilingües equilibrados, ¿tiene el equilibrio un impacto positivo en el dominio del idioma? Y especialmente cuando los niños comienzan a asistir a la escuela y en consecuencia reciben mucha información oral y escrita en el idioma de la escuela, ¿cómo se desarrollan el equilibrio y el dominio? El presente trabajo discute las siguientes preguntas de investigación con respecto al vocabulario: ¿Los resultados equilibrados de las pruebas en dos idiomas se correlacionan mejor que los resultados desequilibrados con una mejor competencia? ¿Y va el uso equilibrado de dos idiomas acompañado de un vocabulario equilibrado? Utilizamos una tarea de identificación de imágenes para poner a prueba el vocabulario productivo y receptivo de 98 escolares germano-turcos en un diseño transversal. Los resultados en alemán y en turco fueron sustraídos para determinar el índíce de equilibrio/dominio respectivo. Las puntuaciones de vocabulario muestran un cambio continuo al dominio en el lenguaje mayoritario. El uso constante del turco tiene un efecto en el vocabulario turco, pero no tiene un impacto negativo en el vocabulario en alemán. No hubo una influencia positiva general del bilingüismo equilibrado.

\section{Zusammenfassung}

Ausgewogenheit hat die Debatten über Bilingualität oft inspiriert; doch wie häufig sind ausgewogene Zweisprachige, und hat Ausgewogenheit einen positiven Einfluss auf Sprachbeherrschung? Diese Fragen untersuchen wir mit dem Fokus auf den ersten Schuljahren, in der die Kinder einen hohen Anteil ihres Inputs in der Schulsprache erhalten. Wir diskutieren die folgenden Forschungsfragen in Bezug auf den Wortschatz: Korrelieren ausgewogene Testergebnisse in zwei Sprachen mit insgesamt stärkeren Testergebnissen? Geht ein ausgewogener Gebrauch von zwei Sprachen mit einem ausgewogenen Wortschatz einher? Dafür wurden 98 Deutsch-Türkisch-sprachige Schülerinnen und Schüler in einem Querschnittsdesign mit einem Bildbenennungstest auf expressiven und rezeptiven Wortschatz untersucht. Durch Subtraktion der türkischen Ergebnisse von den individuellen deutschen Resultaten wurde ein Dominanz-/Balanceindex für jedes Kind errechnet. Die Testergebnisse zeigen eine kontinuierliche Verschiebung zu einer Dominanz in der Mehrheitssprache Deutsch. Die konsequente Verwendung des Türkischen in der Familie wirkt sich positiv auf den türkischen Wortschatz aus, nicht aber negativ auf den deutschen Wortschatz. Wir fanden keinen positiven Effekt von Ausgewogenheit. Als mögliche Einschränkung wird angemerkt, dass die Verwendung desselben Testverfahrens in mehreren Sprachen aufgrund von Testeffekten einzelne Sprachgruppen bevorzugen könnte.

\section{Keywords: vocabulary, dominance, balance, primary school, Turkish, German}




\section{Introduction}

The number of children being raised in immigrant background families is large, and this number is increasing globally, especially in Western Europe; however, the course of language development of these children is poorly described or is rarely the focus of research (see Rehbein, 2001; Jørgensen, 2003; Backus, 2013, for overviews of Turkish background children in Europe). Besides other questions, studies have asked whether these mainly early sequential bilingual children from Turkish diaspora exposed to two languages during primary school acquire their first and second languages at the same rate and in the same way as monolingual children. Many studies on early or late bilingualism have examined vocabulary development. Those studies highlighted the idea that the vocabulary of a bilingual child can constitute an important predictor for L1 maintenance or attrition as well as for overall school success (Cummins, 2014, Genessee \& Nicoladis, 2007) and later literacy development (Rohde \& Thompson, 2007; Mayo \& Leseman, 2008; Lee, 2011). As mentioned in many studies, throughout elementary school, standardised measures of oral language proficiency (expressive and receptive vocabulary size) reveal a gap between monolingual and bilingual children (Bialystok, Luk, Peets \& Yang, 2010; Eilers, Pearson \& Cobo-Lewis, 2006). However, early simultaneously bilingual children have been described as following a developmental course similar to that of monolingual children when both their vocabularies are considered (Pearson \& Fernández, 1994; Patterson \& Pearson, 2004). As for the lexicon development of bilingual children from poor and low socioeconomic backgrounds and from ethnic minorities, especially from Turkish immigrant families in Western Europe, research has found low vocabulary in L1 and L2 when compared to the vocabulary in monolingual children (Allen, Crago \& Pesco, 2006; Meisel, 2007; Schlyter \& Hakansson, 1994; Treffers-Daller, Özsoy \& van Hout, 2007). For instance, Leseman (2000) found that Turkish preschoolers' development of Turkish vocabulary in the Netherlands appeared to be rather similar to Dutch lower-class children's Dutch vocabulary development; at the same time, it was further behind the latter. For Leseman, this was evidence that early gaps tend to widen over time.

Thus, this paper considers lexical development in Turkish and German of 98 German-Turkish speaking schoolchildren in Germany using a picture naming task to test their expressive and receptive vocabulary in both languages. The main purpose of the paper is to discuss, with respect to vocabulary, whether balanced test results in two languages correlate with a better proficiency than unbalanced results. Thus, more specifically, we explore whether a balanced 
use of two languages is accompanied by a balanced vocabulary. Balanced bilingualism has inspired debates on bilingualism for a long time, but how common are balanced bilinguals, and does balance have a positive impact on language proficiency? More specifically, when children begin to frequent schools and thus have a lot of oral and literal input in the school language, how do balance and dominance develop? Regarding the notion of input, this is a very short word for what parents, siblings, teachers, and friends offer children in terms of language: interaction, emotion, social contacts, a turn at talk, an open ear, dialogue, conversation, discussion, (pre)literacy, culture, play, and so on.

This paper is composed of four sections. In the first section, we present the theoretical framework for the study and focus particularly on the relationship between balance and dominance regarding proficiency, use, input, or preference of two or more languages. In the second section, we briefly focus on Turkish immigrants in Germany and especially on research conducted on bilingual children's vocabulary development. The third section presents our methodology, describing participants, measures, and procedures. In the last section, we present the descriptive results of the picture naming test for balance and dominance vocabulary and the impact of exposure and use on vocabulary scores.

\section{Balance and Dominance}

Because bilinguals and multilinguals are not two monolinguals inside one person (Grosjean, 1989), only some speakers have an equivalent proficiency in their languages, while many others have a more profound proficiency or a better fluency in one language (Lambert, Havelka \& Gardner, 1959; Leopold, 1949; Silva-Corvalán \& Treffers-Daller, 2016), resulting in the dominance in one language. Additionally, balance has long been a much-discussed idea in the field of bilingualism (for an overview, see De Houwer \& Bornstein, 2015). Balance and dominance are always relate data, i.e., regarding proficiency, use, input, or preference of two or more languages (Argyri \& Sorace, 2007; Montrul, 2016). The distinctions are gradual, not categorical (Birdsong, 2016). Balance is characterised mostly by equal use, proficiency, or pace of development (Müller, 2004). Dominance is more common than balance: in a study of 258 Luxembourg primary school students, Krampen et al. (Krampen, Blatz, Brendel, Freilinger \& Medernach, 2002) found that, for $26 \%$ of bilinguals and $63 \%$ of trilinguals, performance in naming tasks differed by more than one standard deviation between languages, which indicated unbalanced results. In a survey of German-Turkish adolescents in 
Hamburg, 30-37\% of adolescents indicated that they spoke Turkish better than German, and 54-59\% of respondents indicated that they spoke German better than Turkish (Fürstenau \& Yağmur, 2003). Over his or her lifespan, an individual's language balance may modify or shift, for instance, if conditions change (Bahrick, Hall, Goggin, Bahrick \& Berger, 1994; De Houwer, 2011; Fantini, 1985; Grosjean, 2010; Leopold, 1949), and a late learned language may become the dominant one if used consistently (Tracy \& Lattey, 2009). Dominance, meanwhile, has been described with many different indicators: a better score in proficiency tests, a better fluency, a preferred use of a language, etc.

In this sense, balance and dominance are highly related to the use of languages in different domains for different purposes. The language competence of schoolchildren is highly influenced by educational language practices, and these language practices enable children to develop some languages - the languages spoken at school - better than others.

The methods to examine dominance and balance are manifold: To determine the dominant language with respect to proficiency, in a standardised methodological design, tests are typically conducted in both languages, and the results are compared by using, for example, indices calculated by subtraction or division (Birdsong, 2016). Balance and dominance in proficiency have been studied, for example, with respect to mean length of utterance (Genesee, Nicoladis \& Paradis, 1995; Yip \& Matthews, 2006), lexical diversity (TreffersDaller, 2011), and vocabulary extent (Gathercole \& Thomas, 2009). From the perspective of cognitive processes, reaction times, naming speed, and imaging methods have been carried out (Montrul, 2016; Segalowitz, 2010). For fluency, detailed parent surveys (Unsworth et al., 2014), 24-hour recordings (e.g., Odean, Nazareth, \& Pruden, 2015), or observations of quantity of utterances (Gawlitzek-Maiwald \& Tracy, 1996) have been used. ${ }^{4}$ For older subjects and adults, self-ratings on use and language behaviour can be applied (Daller, Y1ldı, de Jong, Kan \& Başbaği, 2011; Dunn \& Fox Tree, 2009; Goggin, Estrada \& Villarreal, 1994; Gollan, Weissberger, Runnqyist \& Cera, 2012; Marian, Blumenfeld \& Kaushanskaya, 2007). To find out whether language use is balanced or dominant, Lloyd-Smith, Gyllstad, and Kupisch (2017) suggested a questionnaire for Turkish language use, with questions regarding language use by the family, language quality, and language use and experience in Turkey, which are then weighted and brought together as a single score (Lloyd-Smith, Gyllstad \&

\footnotetext{
${ }^{4}$ We regard 'parents' to be those persons within the household that the child has daily contact with.
} 
Kupisch, 2017): for example, schooling experience in Turkey is weighted twice as a factor as the mother's language, and literary education is weighted by a factor of 3 . The question arises, however, regarding which empirical basis the weighting is based on. For global data collection regarding command as well as use, the following is suggested (Paradis \& Nicoladis, 2007): a questionnaire asking for demographics, such as age of acquisition, place of birth, place of residence, and language environment.

Dominance and balance affect other linguistic and cognitive processes. Balance has been found to have a positive effect on executive control (Yow \& Li, 2015), but there have also been cases of balance of two weak proficiencies (Müller \& Pillunat, 2008). Dominance can offer advantages in the speed of word recognition, word completion, and reading in the dominant language (Lambert et al., 1959). Dominance in the fluency of one language has been found to account for reading speed differences in different languages or writing systems (Favreau \& Segalowitz, 1983) or the ability to translate in different directions (Flege, Mackay $\&$ Piske, 2002). Balance and dominance may have different impacts on cognitive and linguistic processing, for instance, on phonological command of a third language (LloydSmith et al., 2017) with respect to high or low proficiency (Bialystok, Craik, Green, \& Gollan, 2009). Transfer is found to be more often (but not only) in the direction of the dominant to the weaker language (Kupisch, 2007; Silva-Corvalán \& Montanari, 2008). A dominant proficiency in one language can result in a preferred use of the other, better mastered language(s) by a child with frequent code-switching (Bernardini \& Schlyter, 2004; Deuchar \& Quay, 2000; Genesee, Nicoladis \& Paradis, 1995). Intensive use of the heritage language at home may be accompanied by better proficiency and cognitive advantages in terms of nonverbal intelligence scores ( Daller \& Ongün, 2017).

One reason for unbalanced proficiency of languages is more exposure to one language with respect to quantity and/or quality. The exposure may originate from, especially in the case of heritage languages, only a few speakers and therefore may show little variability (Allen, Crago \& Pesco, 2006; Meisel, 2007; Schlyter \& Hakansson, 1994; Treffers-Daller et al. 2007). When children start school, their linguistic environment changes to a dominant input of the majority language if the majority language is also the school language, in contrast to a more home-language oriented input in the time before schooling (Montanari, Abel, Graßer \& Tschudinovski, 2018). School language offers the possibility to build up an academic register because literacy education is concentrated on and is often exclusively available in the school 
language. Compared to the focus on literacy and academic terminology at school, when heritage language input is limited to the home environment, children are generally exposed to only the everyday language in the heritage language. Moreover, in cases if heritage language lessons are offered at an institutional level, the quality and content tend to be quite heterogeneous because the qualification of the teachers is extremely diverse, and there are no binding curricula. The duration of the lessons is usually limited to around 90 minutes a week.

Our focus is on the following research questions: How do balance and dominance in vocabulary develop in the first years of school? Specifically, we examine the following questions: How frequent are balance and dominance in the vocabulary? Which changes do we see between the first and fourth grades? Does balance or dominance have an impact on vocabulary mastery? Does balanced or dominant exposure affect vocabulary?

\section{Turkish Immigrants in Germany: Demography, Education, and Language Practices}

Immigration from Turkey to Germany began with recruitment of labour from the mid-1960s to 1973 . Over 2 million people of Turkish heritage constitute one of the largest ethnic and linguistic minorities in Germany, counting naturalised citizens as well as Turkish citizens. Turks have still strong attachment to Turkey, as indicated by frequent holiday trips and a high proportion of marriages to spouses newly immigrated from Turkey (Yağmur \& Akıncı, 2003; Akıncı, 2017; González-Ferrer, 2006).

In Germany, until recently, little attention was given to instruction in German in preschool. As for mother tongue instruction, it is a voluntary option. There are a few primary schools that offer German-Turkish bilingual, biliteracy education. At the secondary level, the existing policy is to conduct early tracking of children into different types of secondary schools. Thus, children who have difficulty in German may be excluded from higher forms of education at an early age. Backus (2013) provided a comprehensive overview of the situation of Turkish speakers, including linguistic studies of language maintenance and shift, acquisition, codeswitching, and development of contact varieties as well as aspects of educational policies in individual countries in Western Europe. Large-scale home language surveys, such as the Multilingual Cities Project in six European cities (Extra \& Yağmur 2004) as well as the SPREEG (Spracherhebung in Essener Grundschulen) project in Essen (Chlosta, Ostermann \& Schroeder, 2003) have shown that the Linguistic Vitality Index of Turkish is relatively high in comparison to other immigrant languages. 
Parents speak Turkish and German, and because there are sizeable Turkish speaking subcommunities, there is also considerable social support for Turkish even, to a limited extent, in the framework of the majority school system. However, the family environment includes nonstandard varieties and language mixing from parents as well as older siblings and other relatives in their close social networks. Pfaff (1993) showed the effects of input and social networks both on developing varieties of Turkish L1 and varieties of German L2 of preschool and primary schoolchildren in different neighbourhoods in Berlin. Ehlich, Bredel, and Reich (2008), whose work focused on identifying children in need of language remediation, stressed the necessity of taking nonstandard as well as standard varieties and registers of both L1 and L2 into account.

So far, few studies systematically relate language proficiencies of bilingual Turkish-German bilinguals, including the investigation of possible effects of mother tongue education on the development of both languages. While for some children, the two languages develop independently and simultaneously, leading to almost balanced bilingualism, for others, language dominance changes over the course of their linguistic development. While immigrant children with a Turkish background show Turkish as a dominant language in early childhood (until age 6), their mother tongue may stagnate or fossilise, compared to monolingual children (Akınc1, 2017). However, it seems that further development of the first language is highly heterogeneous, depending strongly on bilinguals' social class, age, peer group affiliations, and media consumption (for Turkish-German bilinguals: Cindark \& Aslan 2004; for written Turkish proficiencies in Germany: Schroeder 2007).

Knapp's (1997) investigation of Turkish-German bilinguals' textual competence in German shows that pupils who acquired first-language literacy in their country of origin scored better. One of the few studies to examine the effects of mother tongue education on development of both L1 and L2 written competence is Turgut's (1996) investigation of lexical diversity, syntactic errors, and complex sentences in written texts of pupils who attend L1 courses. He showed a positive correlation between competence in Turkish and German.

As for earlier studies in which languages among Turkish-German bilinguals were investigated, with a particular focus on vocabulary (Daller, van Hout \& Treffers-Daller, 2003; Pfaff, Yılmaz, Dollnick \& Akınc1, 2012), it is clear that not all children and adolescents who 
live in the same area and attend the same school have similar sociolinguistic patterns. Individual differences in vocabulary are related to participants' and families' sociobiographies and language use patterns. Our previous papers have shown differences in syntactic development, orthography, and written usage (Akınc1, Pfaff \& Dollnick, 2009).

Daller et al. (2003) accounted in their research indices for the lexical items used in an oral text production task by two groups of Turkish-German bilinguals: one group had a Germandominant bilingual competence, and the other one consisted of Turkish-dominant bilinguals. They showed that the proficiency profiles of Turkish-German bilinguals differed significantly from each other depending on whether they lived in Germany or in Turkey. The TurkishGerman bilinguals in Germany were clearly dominant in German in that they obtained higher scores on various measures of lexical richness in German but lower scores in Turkish, and the opposite was true for Turkish-dominant bilinguals who had returned to Turkey eight years prior to the recording.

Willard Agache, Jäkel, Glück, and Leyendecker (2015) examined language vocabulary for 119 preschoolers and 121 fourth-grader Turkish bilinguals from immigrant background families in Germany and analysed link children's Turkish vocabulary to the family background (parents' education and generational status), the home literacy environment (HLE), and mothers' language use. The main findings of this research are summarised as follows: (i) the HLE predicts children's Turkish vocabulary, (ii) mothers' use of Turkish with their children predicts children's Turkish vocabulary, and (iii) family background is mainly connected to Turkish vocabulary by way of mothers' use of Turkish. The HLE and exposure to Turkish are both important for children's heritage vocabulary.

\section{The Study}

\subsection{Participants}

We tested $N=98$ Turkish-German-speaking children aged $6 ; 3$ to $10 ; 10$ years $(M=8 ; 9$, $S D=1 ; 16)$ in both languages. All the participants were born in Germany and lived with at least one Turkish speaking parent or caregiver. The surveys were conducted in primary schools in several Northern German cities; $13.3 \%$ of children attended the first grade, $28.6 \%$ attended the second grade, $34.7 \%$ attended the third grade, and $23.5 \%$ attended the fourth grade. We had $53.1 \%$ girls in the sample. The environment language and teaching medium were 
German, with the exception of school lessons in English or Turkish (45-90 min. per week). A total of $65.3 \%$ of children received additional support in their mother tongue at school or at a club.

Regarding socioeconomic status, the median of the net income of the families per month was $€ 2,001-2,500$. The education level of the parents was of middle-high level (table 1):

Table 1: Highest education degree in $\%$ of the sample, differentiated for mothers and fathers

\begin{tabular}{|l|c|c|c|c|}
\hline & University degree & $\begin{array}{c}\text { Higher education } \\
\text { entrance } \\
\text { qualification }\end{array}$ & $\begin{array}{c}\text { Secondary school } \\
\text { degree }\end{array}$ & $\begin{array}{c}\text { Without a } \\
\text { degree }\end{array}$ \\
\hline Mothers & 17.9 & 26.8 & 48.2 & 7.1 \\
\hline Fathers & 25 & 23.1 & 38.4 & 13.5 \\
\hline
\end{tabular}

In the whole German population, $16 \%$ have a university degree, $29.5 \%$ have a higher education entrance qualification, $55.6 \%$ have secondary school education, and $3.9 \%$ do not have a school leaving certificate. ${ }^{5}$ Thus, the parents of the sample did not differ from the German population with respect to education level. A total of $35.7 \%$ of the mothers and $50 \%$ of the fathers passed the highest exam in Turkey and were consequently regarded firstgeneration immigrants. The learned and practiced professions of the parents expressed in values on the median of ISEI (International Socio-Economic Index of Occupational Status Schimpl-Neimanns, 2004) were as follows: mothers - learned: 32; fathers - learned: 34; mothers - practiced: 0; fathers - practiced: 32.5; the mean of ISEI for German men was 44, and consequently, the professional level in the sample was lower than in the mean of the German population.

\subsection{Measures}

With respect to language exposure at home, we regarded exposure patterns as Turkishdominant exposure by parents when one parent mainly spoke Turkish and the other parent predominantly spoke either Turkish or both languages. ${ }^{6} \mathrm{We}$ considered patterns as Germandominant exposure when one parent addressed the child predominantly in German and the

\footnotetext{
${ }^{5}$ Data 2015 DeStatis

https://www.destatis.de/DE/ZahlenFakten/GesellschaftStaat/BildungForschungKultur/Bildungsstand/Bildungssta nd.html

${ }^{6}$ We had two one-parent families in our sample; we excluded them from this calculation because the item could not be answered completely.
} 
other parent addressed the child in either or both languages or predominantly in German. In balanced exposure, both parents talked to the child in Turkish and in German (Type A) or used a single language - the one-person strategy OPOL (one person, one language; Type B).

To calculate the dominance or balance of vocabulary, we subtracted, for every individual, the raw values in the Turkish test from the values in German (for discussion of subtraction versus ratio, see Birdsong 2016). Positive values showed better results in German and, in this sense, a German-dominant score, whereas negative values showed a Turkish-dominant score and better results in Turkish. ${ }^{7}$ Values around 0 represented a balanced bilingual with similar test results in both languages. In determining the range around zero that was regarded as balanced vocabulary, we oriented on the mean standard deviation of the expressive performance, 17.27 (see Treffers-Daller et al. 2007). School-grade-specific standard deviations ranged from 12.25 to 14.59 . We decided to apply an idealised standard deviation of 15 and defined values between -15 to 15 as the 'balanced range'. 8

The vocabulary in both languages was calculated as total vocabulary (TV) and total conceptual vocabulary (TCV; Pearson, Fernández, \& Oller, 1993). For TV, the raw values in both languages of an individual were added (one item named in both languages resulted in two points); for TCV, the named concepts in both languages were added (one item named in both languages resulted in one point). In our analysis, we always controlled for the age of the children.

\subsection{Procedure}

The participants were tested with a standardised naming task for children aged $5 ; 6$ to $10 ; 11$ years WWT 6-10 (Wortschatz- und Wortfindungstest für 6- bis 10-Jährige, Glück, 2011). The test was developed in German and Turkish versions and had 95 items (26 nouns, 23 verbs, 23 adjectives, and 23 category nouns). The items were chosen with respect to word length in syllables as indicators for phonological complexity, frequency as indicated in the Corpus 'Deutscher Wortschatz' of the Institut für Deutsche Sprache of the University of Leipzig, semantic domain according to the classification of Dornseiff, Quasthoff, and Wiegand (2004),

\footnotetext{
${ }^{7}$ The issue of which language should be subtracted needed to be discussed. In this sample, we had no Turkishdominant children; a subtraction of German values from the Turkish scores would have produced negative numbers for all the bilingual children in the sample. We would not have found it appropriate to give only negative numbers to bilingual knowledge.

${ }^{8}$ Regarding individuals, for a qualitatively oriented discussion of balance/dominance patterns and focus on individual diversity, please refer to Montanari, Graßer, Tschudinovski, and Abel (2018)
} 
and word class, differentiating nouns, headings, verbs, and adjectives (Glück 2011: 29 ff.; please note the item list in the appendix). The German standardisation of the WWT 6-10 was carried out in 2004 with a standard sample of 880 monolingual German-speaking children (Glück 2011, 28ff.), and a comparative study was conducted with 54 Turkish children (Glück 2011, 19). We tested receptive and expressive vocabulary, that is, children were asked to name items for which they were shown a photo ('What is that?'/'What does s/he do?', 'What is the opposite of....?'). In the receptive test, the children chose one of four pictures ('Point to “crown”!'). The tests were conducted by specially trained bilingual German-Turkish speakers. The children were tested at intervals of one to four weeks in random language order; the average testing time was about 50 minutes. All test protocols were checked after the testing using audio recordings. The test was stopped if the child could not name 5 successive items.

Interviews were conducted with all the children before testing in German or Turkish and documented with paper and pencil in an interview guide sheet. The parents were interviewed with a questionnaire in German and Turkish. We received completed questionnaires from $60.2 \%$ of the families. The questionnaires included information on the linguistic biography of the child (e.g., start of language contact, input), the languages of the child and his or her parents (e.g., language proficiency, language use in the family and in concrete situations), linguistic activities in the family (e.g., reading and storytelling habits, number and languages of the child's books), and the family social environment (e.g., educational attainment, etc.). ${ }^{9}$ Regarding exposure, the children were asked in which language their mother and father spoke to them, in Turkish, German, or both, and in which languages they answered (Fig. 1, 2).

\section{Which languages do you use while talking to your child?} Please colour the proportion in the bar for each language.

Example: Mother speaks Turkish more often than German.

German Turkish

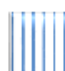

\footnotetext{
${ }^{9}$ Language use with adults other than parents is another important approach, but we did not receive reliable answers from the children - some children mentioned all their relatives, even if they met them only occasionally during holidays, whereas other children were very selective in their answers; consequently, we excluded these data from the analysis.
} 
Fig. 1: Item in the parents' questionnaire: Which languages do you use when you talk to your child?

Further, the children were asked about their use of languages with siblings and friends. The parents were also asked to indicate the exposure of the child during the day in slots of two hours.

When is your child exposed to German; when is your child exposed to Turkish?

Example:

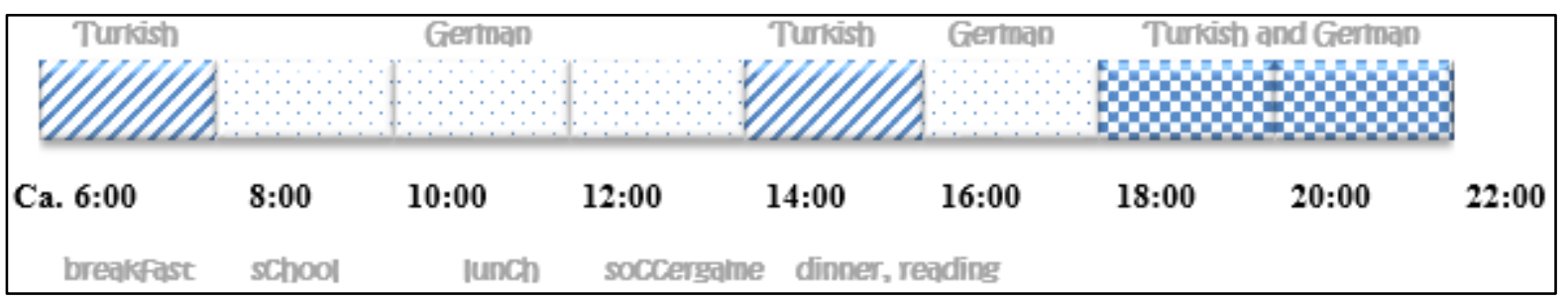

Fig. 2: Example of time of exposure to languages

\section{Results}

\section{Descriptive results: Balance and dominance of exposure and use}

In the morning, exposure is strongly dominated by German, a fact that is easy to explain: schooling in Germany usually takes place between 8 am and 2 pm (Fig. 3).

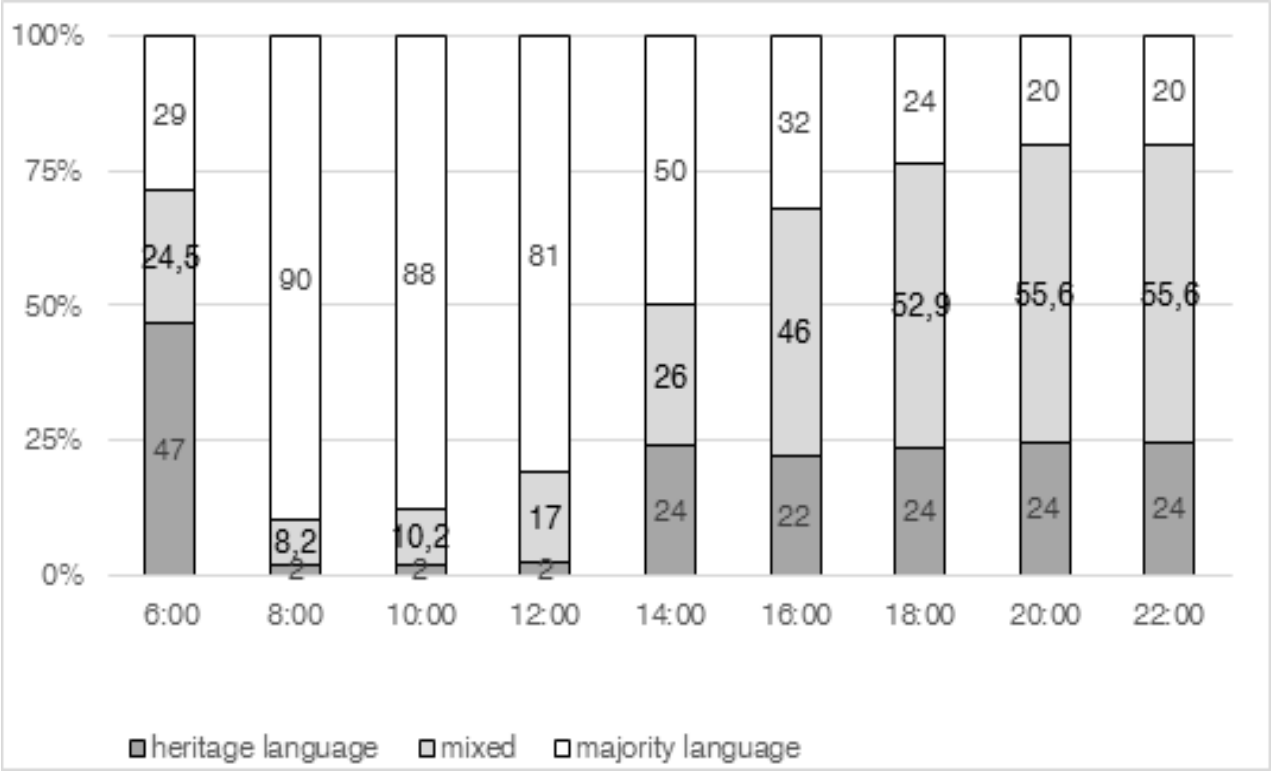

Fig. 3: Parents' answers about exposure during a school day 
In the afternoon, more children receive input in Turkish or in both languages. For instance, at $4 \mathrm{pm}, 32 \%$ of the parents answered that their child is exposed to German, $46 \%$ answered that the child hears both languages, and $22 \%$ of the parents answered that their child hears Turkish. At home, $56.1 \%$ of the children receive Turkish-dominant exposure, $9.2 \%$ receive German-dominant exposure, and $34.7 \%$ receive balanced exposure (Fig. 4).

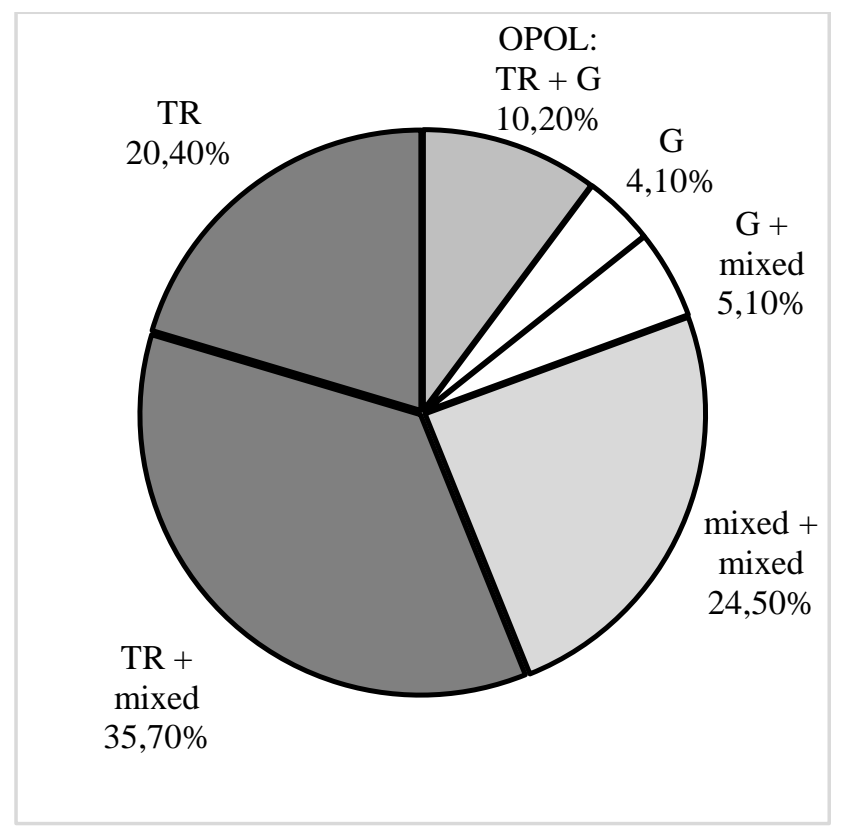

Fig. 4: Parental language exposure patterns (one parent + other parent). Dark grey Turkish-dominant exposure at home; pale grey - balanced exposure at home; white German-dominant exposure at home ${ }^{10}$

We found a significant symmetry in the language to which a child is exposed at home and the language use of the child. The Pearson Chi square test provides highly significant evidence of the correspondence between the language of addressing and the language use of the child when interacting with the mother $\operatorname{chi}^{2}(4,97)=46.46, p<.001$; the father $\operatorname{chi}^{2}(4,95)=60.62$, $p<.001$; the older $c h i^{2}(4,59)=76.00, p<.001$; and the younger siblings $c h i^{2}(4,40)=51.24$, $p<.001$. Consequently, we assumed that the parental address and language use in the family showed the same pattern.

\section{Language use with peers}

Talking with peers is another important source of input and language use. Regarding siblings, the children in the sample spoke mostly German or both languages to older siblings $(40.2 \%$ of

\footnotetext{
${ }^{10} \mathrm{TR}=$ Turkish; $\mathrm{G}=$ German; mixed=use of both languages; OPOL: one person, one language, one parent speaks Turkish, the other one speaks German
} 
the children had no older siblings; of the remaining 59.8\%, 26.5\% of the children used German with older siblings, $30.4 \%$ used both languages, and only $2.9 \%$ used Turkish). A total of $57.8 \%$ of the children did not have younger siblings, or they were infants. Of the remaining $42.2 \%, 21.6 \%$ of the children spoke German with younger siblings, $14.7 \%$ spoke both languages, and only 5.9\% spoke Turkish. Regarding language use with friends, $21.4 \%$ of the children claimed to have friends with whom they exclusively spoke German. Another 78.6\% spoke German and Turkish with their friends: $53.1 \%$ reported seeing Turkish speaking friends (almost) every day, $14.3 \%$ reported seeing them 1-2 times a week, $8.2 \%$ reported seeing them less often than once a week, and $3.1 \%$ reported seeing them only during vacations. To sum up, regular use of Turkish with peers was reported by $53.1 \%$ of the children.

\section{Balance and dominance in the vocabulary test results}

For German, many children obtained only low scores in the expressive testing, with high variation $(M=41.23, S D=17.06$, for 95 items; Fig. 5). The scatter diagram shows the expressive scores for German and Turkish as coordinates. The children who interrupted the expressive testing in Turkish (values 0 of the $\mathrm{x}$-axis) demonstrated great variance in German $(M=44.97, S D=17.22)$. They also performed marginally better in German than the children who successfully completed the test in Turkish $(M=38.76, S D=16.64): t(96)=1.78, p=.078$. Taking age as a covariate into account, the outcomes in Turkish and German did not correlate: $r(56)=.053, p=.693$.

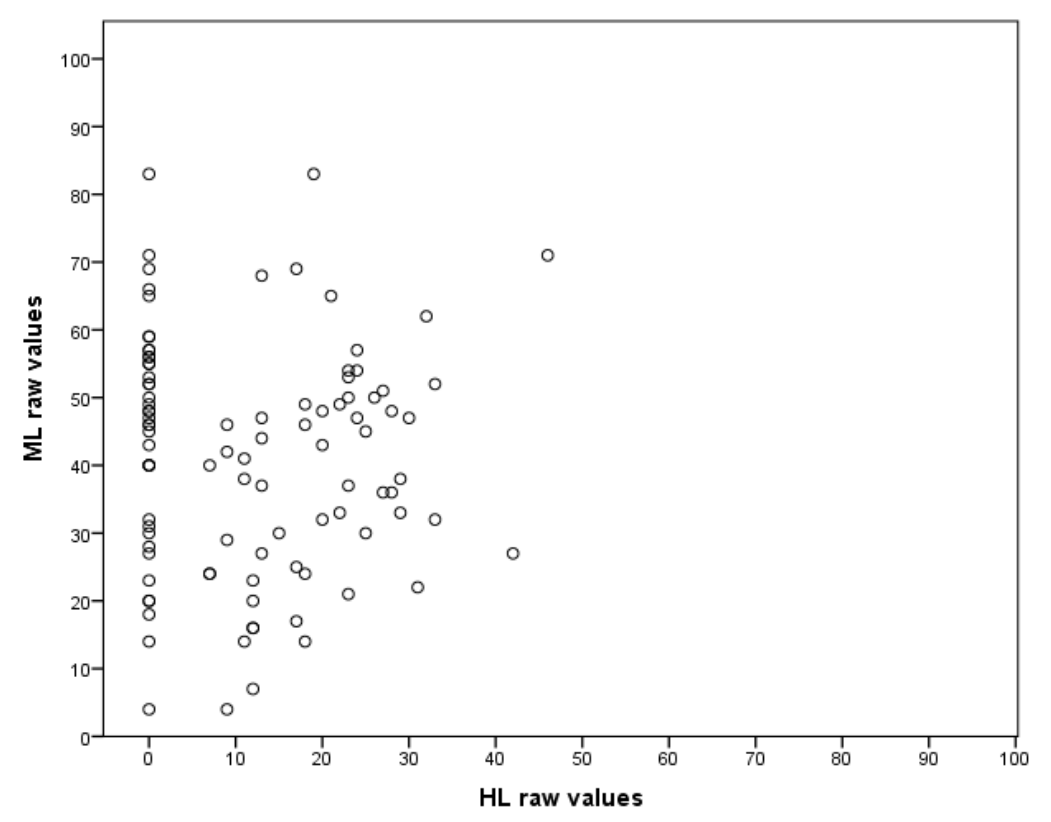


Fig. 5: Expressive vocabulary in Turkish (coordinate of $x$-axis) and German (y-axis) in individual raw values

For receptive vocabulary in German, the average performance was $M=83.84(S D=10.22)$. In Turkish, the mean test scores were lower (expressive: $M=11.99$, median=11.50, $S D=11.85$; receptive: $M=58.98, S D=23.83)$. Expressive vocabulary in German develops at a faster pace than in Turkish $\left(\eta^{2}=.399\right.$ vs. 212$)$.

As we mentioned before, we calculated balance and dominance via subtraction of the individual expressive scores in both languages. The individual results lay between -15 and 83 $(M=29.26, S D=20.65)$; one child's score was exactly at the boundary of -15 and consequently still had a balanced score in our terminology, and $27.6 \%$ scores were balanced. Within the balanced group, the test results in Turkish were slightly higher than in German for only five participants. We found no dominant Turkish vocabulary score. We also did not find an abrupt break between balanced and dominant speakers, but rather a normal distribution: ShapiroWilk Test was not significant $p=.290$. Figure 6 shows the balance/dominance results for four years of schooling.

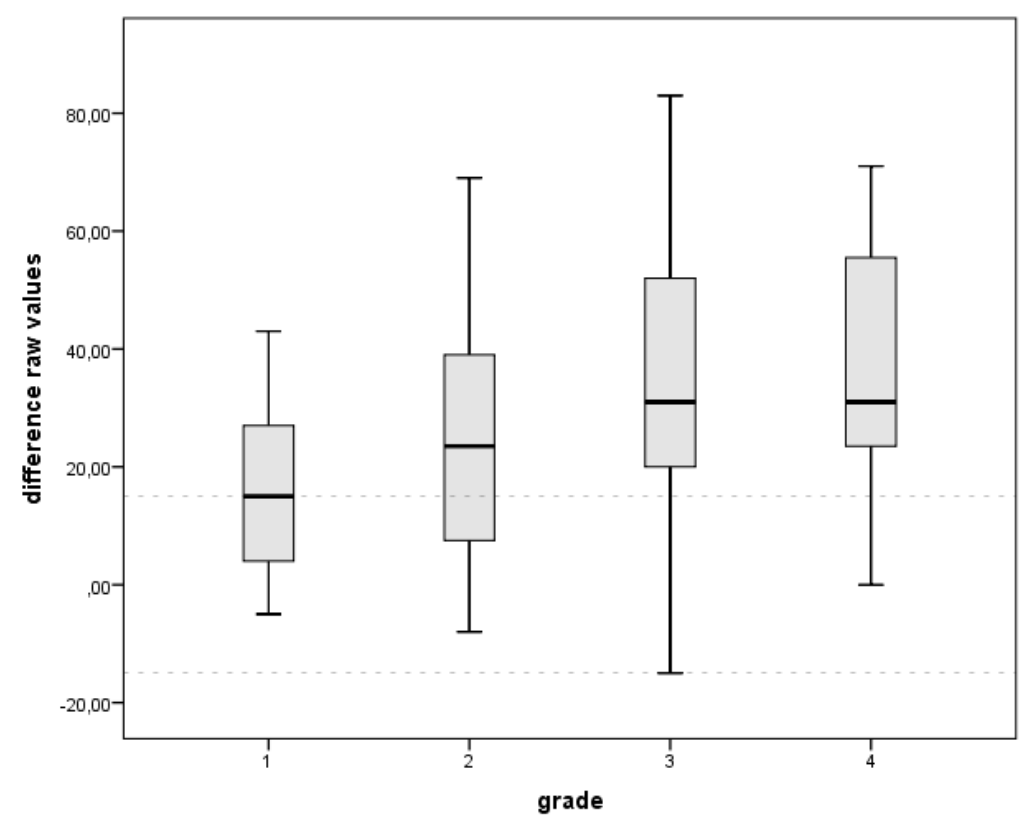

Fig. 6: Vocabulary dominance in subtracted individual values (German - Turkish) over four grades of primary school. Balanced speakers are considered those between the borders of values -15 and 15; see dotted lines. Results above and - theoretically - below are considered indicators for dominant speakers. The median moves towards German dominance. 
The median in the first grade was still at the end of the balanced range $(m=15)$, with slightly better results in German and shifts towards $m=31$ in the third grade and consequently a higher dominance of German in grades 3 and 4. The variance increased from $S D=15.69$ in the first grade to $S D=20.41$ in the third grade and $S D=20.24$ in the fourth grade. ANOVA showed a marginally significant shift towards a stronger vocabulary in German over four years: $F(3,94)=4.03, p=.010, \eta^{2}=.114$. A significant difference was found between the first and third/fourth grades $p s<.05$, but not in the second grade Vocabulary dominance of German and the age of the children were significantly correlated $r=.273, p=.007$ : the older the children, the stronger the dominance. The shift to German dominance was confirmed by the ratio of balanced versus German-dominant children as categorical variables in the Chi square test $c h i^{2}$ $(3,98)=8.69, p=.034$.

We checked the results for groups: the variance for balanced results was smaller than for German-dominant results (balanced: $N=27.6 \%$, German: $M=23, S D=10$, Turkish: $M=19$, $S D=10$; dominant: $N=72.4 \%$, German: $M=48, S D=14$, Turkish $M=9, S D=12$ ). Controlling for age, the mean scores in Turkish of the balanced group were higher than in the Germandominant group (balanced: $M=19, S D=10$ vs. dominant: $M=9, S D=12$ ): $F(1,95)=33.94$, $\left.p<.001, \eta^{2}=.263\right)$. The mean results in German in the balanced group were lower than in the German-dominant group (balanced: $M=23, S D=10$ vs. dominant: $M=48, S D=14$ ). ANOVA showed a very clear difference $F(1,95)=58.22, p<.000$, with a higher effect size of $\eta^{2}=.380$.

In a comparison of the added results in both languages as the TV for balanced and Germandominant children, the following picture emerged (Fig. 7): 


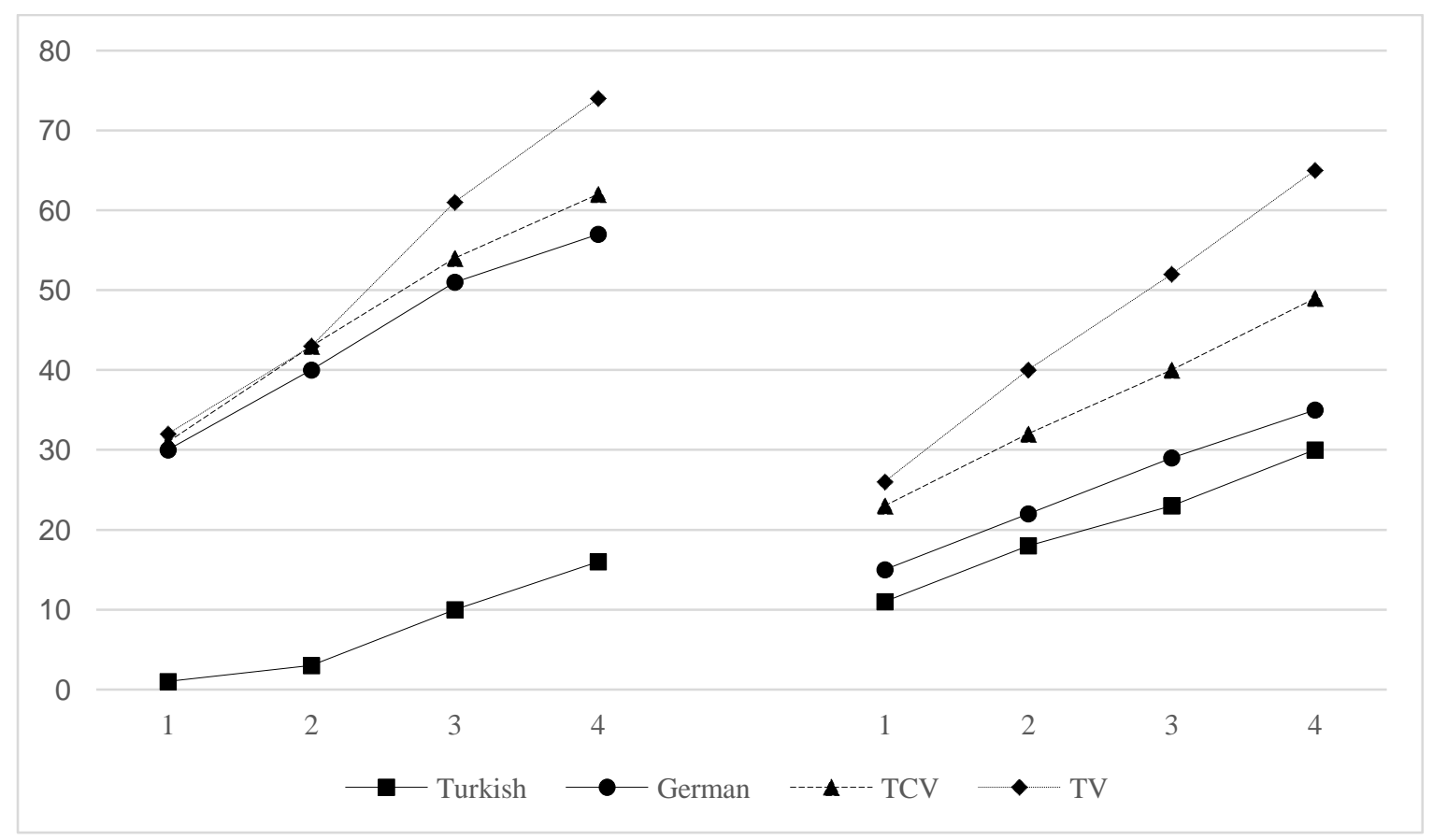

Fig. 7: Cross-sectional comparison of four grades of primary school of two groups: German dominant (on the left) and balanced (on the right) for Turkish, German, and TCV proficiency.

The two scores for TV and TCV were higher for the German-dominant group than for the balanced group (TV: balanced $M=42, S D=18$ vs. dominant $M=57, S D=20 ; F(1,95)=3.53$, $p=.063, \eta^{2}=.036$; TCV: balanced $M=34, S D=12$ vs. dominant $M=51, S D=15 ; F(1,95)=19.171$, $p<.001, \eta^{2}=.168$ ). The variance of the results of children with German-dominant scores was consistently higher in German, TV, and TCV scores than in children with balanced scores. Consequently, an advantage in Turkish in the balanced group did not compensate for the lower results in the German test; the test results indicated a smaller TV for the balanced group.

We also calculated the number of translation equivalents in both languages. For children with German-dominant scores, we found only three concepts on average that could be named exclusively in Turkish. They showed nearly identical values in TCV and German (average TCV is $M=51$ points, German $M=48$, Turkish $M=9$ ). Thus, it follows that the children knew mostly Turkish translation equivalents of German words. For the balanced group, the difference between TCV and German was much larger. Children with balanced results produced much fewer translation equivalents in the test (TCV $M=34$, German $M=23$, Turkish $M=19)$; there were 11 items that were named in Turkish but not in German. The difference 
between the balanced and German-dominant groups for the number of items that could exclusively be named in Turkish was, taking into account age as a covariate, highly significant: $F(1,95)=40.63, p<.001, \eta^{2}=.300$. The expressive vocabulary in German and Turkish, TCV, and TV increased in the cross-sectional design for all the children at the same pace: the ANOVA showed no significance for the interaction term between the dominance type and grade $F s<1$.

\section{Impact of exposure and use on vocabulary scores}

Across all the parental language use patterns, the test results in German were higher than in Turkish (Fig. 8). Parental language use had an impact on the extension of the difference of the test results in Turkish and German: in the two groups with Turkish-dominant language use (HL and HL+mixed), the mean values in German exceeded the mean values in Turkish only for $M=23$ and $M=22$ points, respectively. The difference between the means in Turkish and German of children from balanced home environments with the OPOL pattern or a consistent use of both languages was, with $M=32$ (OPOL) and $M=36$ (both languages), already much higher. The ANOVA showed with respect to age as a covariate, significant differences between parental exposure patterns and naming task results in German, $F(5,91)=3.25, p=.010$, and in Turkish, $F(5,91)=3.13, p=.012$, and therefore in dominance of proficiency in German, $F(5,91)=5.00, p<.001$. However, this does not necessarily mean that children with dominant German input are stronger in German; rather, they show weaker results in the Turkish vocabulary test. Computing a correlation between the exposure index (ML-exposure / HLexposure in the family) and vocabulary, while controlling for age, confirmed that children who have more Turkish exposure have higher scores in Turkish, $r=.364, p=.007$. There was no such correlation for German, $r=.138, p=.138$. 


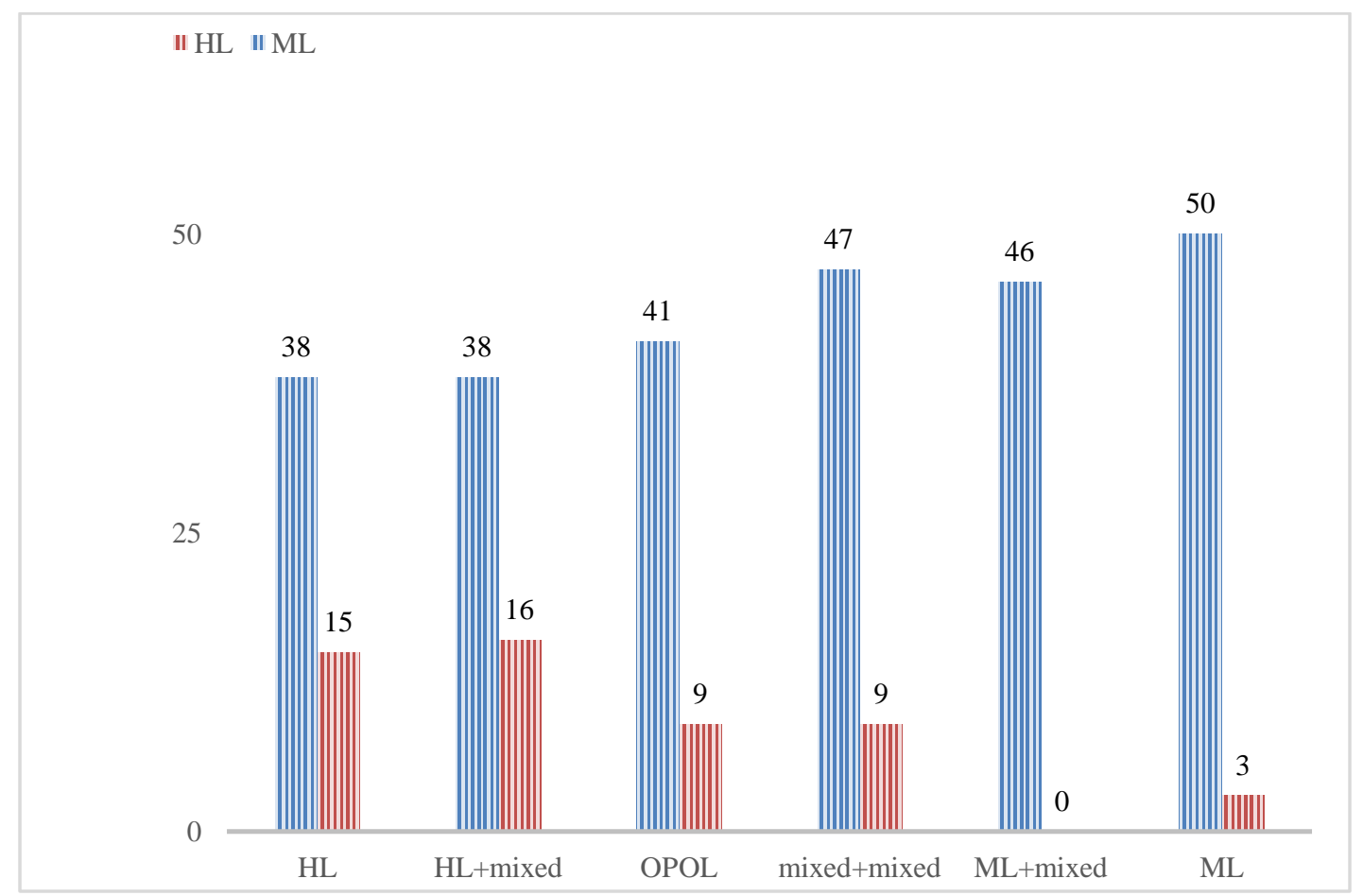

Fig. 8: Proficiency in Turkish (red, HL) and German (blue, ML) depending on exposure patterns

Language use with peers showed an impact, too, $F(4,92)=2.66, p=.038, \eta^{2}=.104$. Children who met Turkish speaking peers more than once a week $(M=25.00, S D=23.79)$ or every day $(M=26.06, S D=19.57)$ were more balanced in their vocabulary scores than children with mostly German speaking friends $(M=35.14, S D=20.26)$. Regarding the impact of the language use of the participants with peers on vocabulary, ANOVA revealed, while controlling for age as a covariate, no impact of language use with older siblings on dominance in German, $F(3,93)=1.27, p=.289, \eta^{2}=.039$, but it did reveal an impact on language use with younger siblings, $F(3,93)=3.54, p=.017, \eta^{2}=.103$. If participants spoke to their younger brothers and sisters in German, they tended to show a stronger German dominance ( $M=40.55, S D=16.99)$ than participants using only Turkish with younger children $(M=17.16, S D=18.37)$, those using both languages with younger children $(M=25.78, S D=17.69)$, or participants without younger siblings $(M=27.46, S D=21.51)$. We checked the results for socioeconomic status and did not find any correlations, with one exception: the higher the ISEI value of the profession of the fathers, the more likely the German vocabulary scores would be dominant $r=.292, p=.035$. 


\section{Discussion}

The first main result on a descriptive level was that although balanced vocabulary scores were not the norm, they were not particularly rare either, especially for young participants. The second finding showed a steady shift towards dominance of the majority language, when it was also the medium of schooling, in the expressive vocabulary of children in the third grade. Third, consistent use of Turkish in the family had a positive effect on Turkish, but no effect on German. Turkish language use with peers contributed to measurable effects in Turkish vocabulary. Fourth, we did not find any Turkish-dominant test results in our sample.

Answering our first research question, Does balance correlate with a higher level of vocabulary?, the results show that balance in itself has no positive effects on either the development of vocabulary in individual languages or the development of overall vocabulary. In the present sample, balance was associated with low vocabulary test results in both languages and in the TV scores (TV and TCV). With respect to our second research question, which asked if a balance of use of two languages correlates with balanced proficiency, the results showed that the quantity of exposure and language use in Turkish had an impact on the degree of dominance in German because more Turkish exposure corresponded with a lesser extent of dominance in German. Exposure does not have a categorical but a modifying effect on proficiency balance; that is, it amplifies or weakens dominance: the more German dominates language use in the family, the bigger the difference between the scores in German and Turkish of the children and the stronger the German dominance.

These results confirmed the distributions of balance and dominance found in preschoolers (Schmeißer et al., 2016) and the benefit of Turkish use at home for Turkish proficiency (Akınc1 \& Yağmur, 2003). The correlational results, which showed that vocabulary size in German is largely independent from language choice and language balance in the family, whereas Turkish vocabulary can profit from more use of Turkish, are an argument in support of Turkish language use at home. This has been found in other studies, but has also been contradicted, for example, in PISA studies (Prenzel, Artelt, Baumert, et al., 2008). With respect to qualitative interests beyond quantitative facts, we interpret this finding to mean that, in the long term, it is not only families that can guarantee bilingualism; rather, qualitatively meaningful and structured educative measures are also necessary to maintain multilingualism. Even if Turkish-dominant language use at home is the most frequent pattern, followed by balanced use, the impact of the environment and of the school is very strong and 
leads to a dominant vocabulary in German. Furthermore, we want to propose how test results should be interpreted in light of multicompetent language use (Cook, 1992; Jessner, 2017). It has been proposed that multilingual children use their languages particularly efficiently, including high language reflection potential, transfer, and borrowing. This has been confirmed, for example, through observation studies (Cook, 1992). However, educational institutional practices are, apart from explicit multilingual institutions, mostly focused on the exclusive or predominant use of the majority language as the medium of instruction. Consequently, the current language practice in institutions produces and reinforces dominance in the majority language.

On the other hand, children adapt their vocabulary to their language needs and their pragmatic options in an ecological way: if children or speakers in socially determined educational contexts have different options to act in one language than in other languages, and if the goals that can be achieved in a society are unequally distributed among languages, then these unequal options for action are also reflected quantitatively, for example, in the vocabulary. This dilemma can be resolved with a multilingual orientation in education policy; if children tend to develop the vocabulary they need most urgently, a multilingual education system would promote a balanced vocabulary.

In light of these results, balance should be discussed, too. Our results contradict the positive connotation associated with balance with respect to proficiency: at a low level, as found here, balance in proficiency can be considered a warning sign. It is clear that balance in language use is a fragile equilibrium - in the first years of life, if the children live with the family, balance can mean that the parents divide the languages as equally as possible. If siblings are added, this equilibrium already shifts because older siblings and friends are more likely to bring exposure to the environment language. When children enter educational institutions, a new balance in language use has to be found: a reasonably well-balanced range of languages does not exist until the German-intensive mornings at school are compensated by predominantly Turkish language use in the afternoon.

To comment on our findings, we think it has to be critically questioned whether the comparison of naming tasks in different languages raises its own difficulties. It should be noted that word frequencies are not the same between languages, and societies categorise and name objects in different ways (Pavlenko, 2011). Even language use may differ between 
languages. On the basis of the German and Turkish corpus of the Leipzig Vocabulary Portal (University of Leipzig), however, we examined the frequency classes of Turkish and German items. For the German version, the items were between the frequency classes 7 and 18; for the Turkish items, they were between 5 and 19 of the corpora. The frequency of the items was therefore not fundamentally different in both languages. The procedure was also used with French, Turkish monolingual, and French-Turkish bilingual children (Ertek, 2017). The finding that Turkish mono- and bilingual children have particularly great difficulties in carrying out these naming tasks was repeated. It is therefore necessary to discuss which crosslinguistic test effects could limit the results. However, if a comparison between languages was intended, using the same items might be a useful, but not perfect, approach to compare between languages.

To sum up, what does balance say about vocabulary? If European societies aim to have balanced multilingual and multicompetent citizens, education systems could and should move more quickly towards using multicompetence and multilingualism in institutions of education.

\section{Acknowledgments}

Our warm thanks go to Barbara Graßer for the direction of the project and to Burcu Gökçay, Bilge Mermertaş, and Lilia Tschudinovski for the testing. We are very grateful to Janet McLaughlin and Ana Maria Iglesias for their helpful comments.

\section{Declaration of interest statement}

The authors certify that they have no affiliations with or involvement in any organisation or entity with any financial interest (such as honoraria; educational grants; participation in speakers' bureaus; membership, employment, consultancies, stock ownership, or other equity interest; and expert testimony or patent-licensing arrangements) or nonfinancial interest (such as personal or professional relationships, affiliations, knowledge, or beliefs) in the subject matter or materials discussed in this manuscript.

\section{References}

Akınc1, M.-A. (2017). Emergent bilingualism of French-Turkish bilingual children in France. In C. Y1ld1z, N. Topaj, R. Thomas \& I. Gülzow (Eds.), The Future of Multilingualism in the German Education System: Russian and Turkish in Focus (pp. 99-127). Frankfurt-am-Main : Peter Lang,.

Akıncı, M.-A., Pfaff, C. \& Dollnick, M. (2009). Orthographic and morphological aspects of written Turkish in France, Germany and Turkey. In S. Ay, Ö Aydin, İ. Ergenç, S. Gökmen, S. İşsever \& D. Peçenek (Eds.) 
Essays on Turkish Linguistics. Proceedings of the 14th International Conference on Turkish Linguistics (pp. 363-372). Wiesbaden: Otto Harrassowitz Verlag.

Allen, S. E. M., Crago, M. B. \& Pesco, D. (2006). The effect of majority language exposure on minority language skills: The case of Inuktitut. International Journal of Bilingual Education and Bilingualism, 9, 578-596.

Argyri, E. \& Sorace, A. (2007). Crosslinguistic influence and language dominance in older bilingual children. Bilingualism: Language and Cognition, 10, 79-99.

Backus, A. (2013). Turkish as an immigrant language in Europe. In T. Bhatia \& W. Ritchie (Eds.), The Handbook of Bilingualism and Multilingualism (pp. 770-790). Oxford: Blackwell (2nd ed.).

Bahrick, H. P., Hall, L. K., Goggin, J. P., Bahrick, L. E. \& Berger, S. A. (1994). Fifty years of language maintenance and language dominance in bilingual Hispanic immigrants. Journal of Experimental Psychology, 123, 264-283.

Bernardini, P. \& Schlyter, S. (2004). Growing syntactic structure and code-mixing in the weaker language: The Ivy-Hypothesis. Bilingualism: Language and Cognition, 7, 49-69.

Bialystok, E., Craik, F. I. M., Green, D. W. \& Gollan, T. H. (2009). Bilingual Minds. Psychological Science in the Public Interest, 10(3), 89-129.

Bialystok, E., Luk, G., Peets, K. F., \& Yang, S. (2010). Receptive vocabulary differences in monolingual and bilingual children. Bilingualism: Language and Cognition, 13, 525-531.

Birdsong, D. (2016). Dominance in bilingualism: Foundations of measurement, with insights from the study of handedness. In C. Silva-Corvalán \& J. Treffers-Daller (Eds.), Language Dominance in Bilinguals: Issues of Measurement and Operationalization (pp. 85-105). Cambridge: Cambridge University Press.

Chlosta, C., Ostermann, T., Schroeder, C. (2003). Die 'Durchschnittsschule' und ihre Sprachen: Ergebnisse des Projekts Sprachenerhebung Essener Grundschulen (SPREEG). ELiS_e, Essener Linguistische Skripte elektronisch, 3(1), 43-139.

Cindark, I. \& Aslan S. (2004). Deutschlandtürkisch? Online: http://www.ids-mannheim.de/ prag/soziostilistik/Deutschlandtuerkisch.pdf.

Cook, V. J. (1992). Evidence for multicompetence. Language Learning, 42(4), 557-591.

Cummins, J. (2014). L'éducation bilingue. Qu'avons-nous appris de cinquante ans de recherche? In Nocus, Isabelle, Vernaudon, Jacques \& Paia, Mirose (Eds.), L’école plurilingue en outre-mer. Apprendre plusieurs langues (pp. 41-63). Rennes: Presses Universitaires de Rennes.

Daller, H., van Hout, R. \& Treffers-Daller, J. (2003). Lexical richness in spontaneous speech of bilinguals. Applied Linguistics, 24, 197-222.

Daller, M. \& Ongün, Z. (2018). The Threshold Hypothesis revisited: Bilingual lexical knowledge and nonverbal IQ development. International Journal of Bilingualism, 22(6), 675-694.

Daller, M. H., Yıldız, C., de Jong, N. H., Kan, S. \& Başbaği, R. (2011). Language dominance in TurkishGerman bilinguals: Methodological aspects of measurements in structurally different languages. International Journal of Bilingualism, 15, 215-236.

De Houwer, A. (2011). Language input environments and language development in bilingual acquisition. Applied Linguistics Review, 2, 221-240.

De Houwer, A., \& Bornstein, M. H. (2015). Balance patterns in early bilingual acquisition: A longitudinal study of word comprehension and production. In C. Silva-Corvalán \& J. Treffers-Daller (Eds.), Language Dominance in Bilinguals: Issues of Measurement and Operationalization (pp. 134-155). Cambridge: Cambridge University Press.

Deuchar, M. \& Quay, S. (2000). Bilingual acquisition: Theoretical implications of a case study. Oxford: Oxford Universitiy Press.

Dornseiff, F., Quasthoff, U., \& Wiegand, H. E. (2004). Der deutsche Wortschatz nach Sachgruppen (8. Edition.). Berlin: De Gruyter.

Dunn, L. M. \& Fox Tree, J. (2009). A quick, gradient bilingual dominance scale. Bilingualism: language and cognition, 12, 273-289.

Ehlich, K. (2007). Sprache Und Sprachliches Handeln. Berlin: Walter de Gruyter.

Ehlich, K., Bredel, U. \& Reich, H. H. (2008). Referenzrahmen zur altersspezifischen Sprachaneignung. Berlin: BMBF (29.I and 29.II)

Eilers, R. E., Pearson, B. Z. \& Cobo-Lewis, A. B., (2006). Social factors in bilingual development: The Miami experience. In P. McCardle \& E. Hoff (Eds.) Childhood bilingualism: Research on infancy through school age (pp. 68-90). Clevedon: Multilingual Matters.

Ertek, B. (2017). Développement du vocabulaire en turc et en français d'élèves bilingues franco-turcs et monolingues turcs et français âgés de 6 ans à 10 ans. Upublished PhD Dissertation. Rouen: Université de Rouen Normandie.

Extra, G. \& Yağmur, K. (2004). Urban multilingualism in Europe: Immigrant minority languages at home and school. Clevedon: Multilingual Matters. 
Fantini, A. E. (1985). Language acquisition of a bilingual child: A sociolinguistic perspective. Clevedon: Multilingual Matters.

Favreau, M. \& Segalowitz, N. (1983). Automatic and controlled processes in the first - and second language reading of fluent bilinguals. Memory and Cognition, 11, 565-574.

Flege, J. E., Mackay, I. R. A. \& Piske, T. (2002). Assessing bilingual dominance. Applied Psycholinguistics, 23, 567-598.

Fürstenau, S. \& Yağmur, K. (2003). Verteilung und Klassifizierung der Herkunftssprachen. In S. Fürstenau, I. Gogolin, \& K. Yağmur (Eds.), Mehrsprachigkeit in Hamburg. Ergebnisse einer Sprachenerhebung an den Grundschulen (pp. 39-46). Münster: Waxmann.

Gathercole, V. C. M. \& Thomas, E. M. (2009). Bilingual first-language development: Dominant language takeover, threatened minority language take-up. Bilingualism: Language and Cognition, 12(2), 213237.

Gawlitzek-Maiwald, I. \& Tracy, R. (1996). Bilingual boot strapping. Linguistics, 34, 901-926.

Genesee, F. \& Nicoladis, E. (2006). Bilingual First Language Acquisition. In, E. Hoff \& M. Shatz (Eds.), Blackwell Handbook of Language Development (pp. 324-342). Oxford: Blackwell Publishing.

Genesee, F., Nicoladis, E., \& Paradis, J. (1995). Language differentiation in early bilingual development. Journal of Child Language, 22(3), 611-631.

Glück, C. W. (2011). WWT 6-10. Wortschatz- und Wortfindungstest für 6- bis 10-Jährige. Göttingen: Hogrefe.

Goggin, J., Estrada, P. \& Villarreal, R. (1994). Picture-naming agreement in monolinguals and bilinguals. Applied psycholinguistics: psychological and linguistic studies across languages and learners, 15, $177-$ 194.

Gollan, T. H., Weissberger, G. H., Runnqyist, E., Montoya, R. I., \& Cera, C. M. (2012). Self-ratings of spoken language dominance: A Multilingual Naming Test (MINT) and preliminary norms for young and aging Spanish-English bilinguals. Bilingualism: language and cognition, 15, 594-615.

González-Ferrer, A. (2006). Who do immigrants marry? Partner choice among single immigrants in Germany. European Sociological Review, 22, 171-185.

Grosjean, F. (1989). Neurolinguists, Beware! The bilingual is not two monolinguals in one person. Brain and Language, 36, 3-15.

Grosjean, F. (2010). Bilingual Life and Reality. Cambridge: Harvard University Press.

Jessner, U. (2017). Multicompetence approaches to language proficiency development in multilingual education. In O. García, A. Lin \& S. May (Eds.), Bilingual and Multilingual Education. Encyclopedia of Language and Education (3rd ed.) (pp 161-173). Berlin: Springer.

Jørgensen, J. N. (2003). Bilingualism and Social Relations. Turkish Speakers in North Western Europe. Clevedon: Multilingual Matters.

Knapp, W. (1997). Schriftliches Erzählen in der Zweitsprache. Tübingen: Niemeyer.

Krampen, G., Blatz, H., Brendel, M., Freilinger, J., \& Medernach, J. (2002). Komparative Befunde zur Wortschatzentwicklung und Sprachförderdiagnostik bei multilingualen Primarschulkindern. Zeitschrift für Entwicklungspsychologie und Pädagogische Psychologie, 34(4), 164-200.

Kupisch, T. (2007). Determiners in bilingual German-Italian children: What they tell us about the relation between language influence and language dominance. Bilingualism: Language and Cognition, 10(1), 57-78.

Lambert, W. E., Havelka, J. \& Gardner, R. C. (1959). Linguistics manifestations of bilingualism. American Journal of Psychology, 72, 77-82.

Lee, J. (2011). Size matters: Early vocabulary as a predictor of language and literacy competence. Applied Psycholinguistics, 32, 69-92.

Leopold, W. F. (1949). Speech Development of a Bilingual Child: A Linguist's Record (Vol. 4). Evanston, IL: Northwestern University Press.

Leseman, P. P. M. (2000). Bilingual vocabulary development of Turkish preschoolers in the Netherlands. Journal of Multilingual and Multicultural, 21(2), 93-112.

Lloyd-Smith, A., Gyllstad, H. \& Kupisch, T. (2017). Transfer into L3 English. Linguistic Approaches to Bilingualism, 7(2), 131-162.

Marian, V., Blumenfeld, H. K., \& Kaushanskaya, M. J. (2007). The Language Experience and Proficiency Questionnaire (LEAP-Q): Assessing language profiles in bilinguals and multilinguals. Journal of Speech, Language, and Hearing Research, 50(4), 940-967.

Mayo, A. Y. \& Leseman, P. P. M. (2008). Off to a good start? Vocabulary development and differences in early family and classroom experiences of children from native-Dutch and immigrant families in the Netherlands. Educational \& Child Psychology, 25(1), 70-82.

Meisel, J. M. (2007). Exploring the limits of the LAD. A collection of four papers. Arbeiten zur Mehrsprachigkeit, 80 . 
Montanari, E. G., Abel, R., Graßer, B. \& Tschudinovski, L. (2018). Do bilinguals create two different sets of vocabulary for two domains? Vocabulary development and overlap in the first years of schooling. Linguistic Approaches to Bilingualism, 8(4), 502-522.

Montanari, E. G., Graßer, B., Tschudinovski, L. \& Abel, R. (2018). Diversität in der Wortschatzentwicklung bilingualer Schülerinnen und Schüler. In J. Ricart Brede, D. Maak, \& E. Pliska (Eds.), Deutsch als Zweitsprache und Mehrsprachigkeit - vielfältige Perspektiven (pp. 17-36). Stuttgart: Klett Fillibach.

Montrul, S. (2016). On the Acquisition of Heritage Languages. Cambrige: Cambridge University Press.

Müller, N. (2004). Null arguments in bilingual children. French topics. In P. Prévost \& J. Paradis (Eds.), The Acquisition of French in Different Contexts: Focus on Functional Categories (pp. 275-304). Amsterdam: Benjamins.

Müller, N., \& Pillunat, A. (2008). Balanced bilingual children with two weak languages: A French/German case study. In P. Guijarro-Fuentes, M. Pilar Larrañaga, \& J. Clibbens (Eds.), First Language Acquisition of Morphology and Syntax: Perspectives across languages and learners (pp. 269-294). Amsterdam: Benjamins.

Odean, R., Nazareth, A., \& Pruden, S. M. (2015). Novel methodology to examine cognitive and experiential factors in language development: combining eye-tracking and LENA technology. Frontiers Psychology, 6, article 1266,1-12.

Paradis, J. \& Nicoladis, E. (2007). The influence of dominance and sociolinguistic context on bilingual preschooler's language choice. The International Journal of Bilingual Education and Bilingualism, 10(3), 277-296.

Patterson, J. L. \& Pearson, B. Z. (2004). Bilingual lexical development: Influences, contexts, and processes. In B. A. Goldstein (Ed.), Bilingual language development and disorders in Spanish-English speakers (pp. 77-104). Baltimore, MD: Paul H. Brookes.

Patterson, J.L. (1998). Expressive vocabulary development and word combinations of Spanish-English bilingual toddlers. American Journal of Speech-Language Pathology, 7, 46-56.

Pavlenko, A. (2011). (Re-)naming the world: Word-to referent mapping in second language speakers. In A. Pavlenko (Ed.), Thinking and Speaking in Two Languages (pp. 198-236). Bristol: Multilingual Matters.

Pearson, B. Z. \& Fernández, S. C. (1994). Patterns of interaction in the lexical development in two languages of bilingual infants. Language Learning, 44(4), 617-553.

Pearson, B. Z., Fernández, S. V. \& Oller, D. K. (1993) Lexical development in bilingual infants and toddlers: Comparison to monolingual norms. Language Learning, 43(1), 93-120.

Pfaff, C., Yılmaz, S., Dollnick, M., \& Akınc1, M.-A. (2012), Development of lexical richness in Turkish written texts of bilingual adolescents in Germany. In E. Kincses-Nagy, (Ed.), Proceedings of 15th International Conference on Turkish Linguistics (pp. 413-422). Szeged: Szeged University Press.

Pfaff, C.W. (1993). Turkish language development in Germany. In G. Extra \& L. Verhoeven (Eds.), Immigrant languages in Europe (pp. 119-157). Clevendon: Multilingual Matters.

Pfaff, C.W. (1998). Changing patterns of language mixing in a bilingual child. In G. Extra \& L. Verhoeven (Eds.) Bilingualism and migration (pp. 97-121). Berlin: Walter de Gruyter.

Prenzel, M., Artelt, C., Baumert, J., Blum, W., Hammann, M., Klieme, E. \& Pe- krun, R. (2008). PISA 2006 in Deutschland. Die Kompetenzen der Jugendlichen im dritten Ländervergleich. Münster: Waxmann.

Rehbein, J. (2001). Turkish in European Societies. Lingua e Stile, 36(2), 317-334.

Rohde, T. E. \& Thompson, L. A. (2007) Predicting academic achievement with cognitive ability. Intelligence, 35, 83-92.

Schimpl-Neimanns, B. (2004). Mikrodaten-Tools. Zur Umsetzung des Internationalen Sozioökonomischen Index des beruflichen Status (ISEI) mit den Mikrozensen ab 1996. Mannheim: ZUMA.

Schlyter, S. \& Hakansson, G. (1994). Word order in Swedish as the first language, second language and weaker language. Scandinavian Working Papers on Bilingualism, 9, 49-67.

Schmeißer, A., Hager, M., Gil, A., Eichler, N., Geveler, J., Hager, M., Jansen, V., Patuto, M. \& Müller, N. (2016). Related but different: the two concepts of language dominance and language proficiency. In C. Silva-Corvalán \& J. Treffers-Daller, (Eds.). Language Dominance in Bilinguals: Issues of Measurement and Operationalization (36-65). Cambridge: Cambridge University Press.

Schroeder, C. (2007). Orthography in German-Turkish language contact. In F. Baider (Ed.), Emprunts linguistiques, empreintes culturelles. Métissage orient-occident (pp. 101-122). Paris: L'Harmattan.

Segalowitz, N. (2010). Cognitive bases of second language fluency. London: Routledge.

Silva-Corvaláan, C., \& Montanari, S. (2008). The acquisition of ser, estar (and be) by a Spanish-English bilingual child: The early stages. Bilingualism: Language and Cognition, 11, 341-360.

Silva-Corvalán, C. \& Treffers-Daller, J. (2016). Language Dominance in Bilinguals: Issues of Measurement and Operationalization. Cambridge: Cambridge University Press.

Tracy, R. \& Lattey, E. (2009). It wasn't easy but irgendwie äh da hat sich's rentiert, net?: A linguistic profile. In S. B. Michaela Albl-Mikasa, Sylvia Kalina (Eds.), Dimensionen der Zweitsprachenforschung. 
Dimensions of Second Language Research. Festschrift für Kurt Kohn (pp. 53-73). Tübingen: Narr Francke Attempo.

Treffers-Daller, J. (2011). Operationalizing and measuring language dominance. International Journal of Biingualism, 15, 147-63., 15, 147-163.

Treffers-Daller, J., Özsoy, A. S. \& van Hout, R. (2007). (In)Complete acquisition of Turkish among Turkish German bilinguals in Germany and Turkey: An analysis of complex embeddings in narratives. International Journal of Bilingual Education and Bilingualism, 10(3), 248-276.

Turgut, A. (1996). Untersuchungen zur Entwicklung der sprachlichen Kompetenz in der Erst- und Zweitsprache bei Türkischen Gymnasiasten. Köln: Önel.

Unsworth, S., Argyri, F., Cornips, L., Hulk, A., Sorace, A. \& Tsimpli, I. M. (2014). The role of age of onset and input in early child bilingualism in Greek and Dutch. Applied Psycholinguistics, 34(4), 765-805.

Willard, J. A., Agache, A., Jaekel, J., Glück, C. W. \& Leyendecker, B. (2015). Family factors predicting vocabulary in Turkish as a heritage language. Applied Psycholinguistics, 36(4), 875-898.

Yağmur, K. \& Akınc1, M.-A. (2003). Language use, choice, maintenance and ethnolinguistic vitality of Turkish speakers in France: Intergenerational differences. International Journal of the Sociology of Language, $164,107-128$.

Yip, V. \& Matthews, S. (2006). Assessing language dominance in bilingual acquisition: A case for mean length utterance differentials. Language Assessment Quarterly, 3, 97-116.

Yow, W. Q. \& Li, X. (2015). Balanced bilingualism and early age of second language acquisition as the underlying mechanisms of a bilingual executive control advantage: why variations in bilingual experiences matter. Frontiers in psychology, 6, Article 164, 1-12. 


\section{Appendix}

Table 2: Grade, mean SD, min. and max. in German expressive and receptive, Turkish resp., best language, TV and TCV

\begin{tabular}{|c|c|c|c|c|c|c|c|c|}
\hline grade & & $\begin{array}{l}\text { ML } \\
\text { expr }\end{array}$ & ML rec & $\begin{array}{l}\text { HL } \\
\text { expr }\end{array}$ & HL rec & $\begin{array}{l}\text { best } \\
\text { language }\end{array}$ & $\mathrm{TCV}$ & TV \\
\hline \multirow[t]{5}{*}{1} & $\mathrm{M}$ & 22,08 & 71,54 & 12,0000 & 57,3000 & 22,8462 & 26,3846 & 28,5385 \\
\hline & SD & 12,251 & 16,215 & 3,36650 & 12,22066 & 11,22383 & 11,04942 & 11,94163 \\
\hline & St.error & 3,398 & 4,497 & 1,27242 & 3,86451 & 3,11293 & 3,06456 & 3,31201 \\
\hline & $\min$ & 4 & 41 & 7,00 & 44,00 & 4,00 & 4,00 & 4,00 \\
\hline & $\max$ & 43 & 87 & 17,00 & 77,00 & 43,00 & 43,00 & 45,00 \\
\hline \multirow[t]{5}{*}{2} & $\mathrm{M}$ & 33,39 & 81,18 & 17,2857 & 61,7600 & 33,8571 & 38,9286 & 42,0000 \\
\hline & SD & 14,801 & 9,456 & 7,74029 & 14,77408 & 14,19628 & 15,81356 & 15,18528 \\
\hline & St.error & 2,797 & 1,787 & 2,06868 & 2,95482 & 2,68284 & 2,98848 & 2,86975 \\
\hline & $\min$ & 14 & 65 & 7,00 & 32,00 & 14,00 & 15,00 & 15,00 \\
\hline & $\max$ & 69 & 94 & 31,00 & 84,00 & 69,00 & 82,00 & 69,00 \\
\hline \multirow[t]{5}{*}{3} & $\mathrm{M}$ & 46,15 & 86,62 & 20,5238 & 67,6000 & 46,5588 & 51,1176 & 58,7941 \\
\hline & SD & 13,392 & 5,075 & 8,16467 & 11,50292 & 13,03652 & 11,80848 & 15,14732 \\
\hline & St.error & 2,297 &, 870 & 1,78168 & 2,10014 & 2,23575 & 2,02514 & 2,59774 \\
\hline & $\min$ & 16 & 76 & 7,00 & 38,00 & 16,00 & 26,00 & 28,00 \\
\hline & $\max$ & 83 & 95 & 42,00 & 83,00 & 83,00 & 82,00 & 94,00 \\
\hline \multirow[t]{5}{*}{4} & $\mathrm{M}$ & 54,35 & 89,91 & 24,5882 & 72,9000 & 54,3043 & 60,3478 & 72,4783 \\
\hline & SD & 12,316 & 4,512 & 8,70387 & 9,88300 & 12,30090 & 9,77292 & 15,46806 \\
\hline & St.error & 2,568 & ,941 & 2,11100 & 2,20991 & 2,56492 & 2,03779 & 3,22531 \\
\hline & $\min$ & 32 & 79 & 11,00 & 54,00 & 32,00 & 47,00 & 52,00 \\
\hline & $\max$ & 83 & 95 & 46,00 & 89,00 & 83,00 & 86,00 & 117,00 \\
\hline \multirow[t]{5}{*}{ overall } & $\mathrm{M}$ & 41,23 & 83,84 & 19,9153 & 65,9176 & 41,6020 & 46,5204 & 53,1939 \\
\hline & SD & 17,063 & 10,226 & 8,61692 & 13,14318 & 16,58762 & 16,65925 & 20,75962 \\
\hline & St.error & 1,724 & 1,033 & 1,12183 & 1,42558 & 1,67560 & 1,68284 & 2,09704 \\
\hline & $\min$ & 4 & 41 & 7,00 & 32,00 & 4,00 & 4,00 & 4,00 \\
\hline & $\max$ & 83 & 95 & 46,00 & 89,00 & 83,00 & 86,00 & 117,00 \\
\hline
\end{tabular}

\section{Items in German and Turkish}

$\begin{array}{lll}\text { B 01 } & \text { Türkisch } & \begin{array}{l}\text { Deutsch } \\ \text { taç }\end{array} \\ \text { K 02 } & \text { resim yapmak } & \text { malen } \\ \text { B 03 } & \text { oyuncak } & \text { Spielzeug } \\ \text { B 04 } & \text { hizlı } & \text { schnell } \\ \text { T 01 } & \text { el arabas1 } & \text { Schubkarre } \\ \text { T 02 } & \text { eski } & \text { alt } \\ \text { T 03 } & \text { yemek } & \text { fressen } \\ \text { T 04 } & \text { oturak } & \text { Hocker } \\ \text { T 05 } & \text { iyi } & \text { lieb }\end{array}$




\begin{tabular}{|c|c|c|}
\hline Т 06 & sebze & Gemüse \\
\hline Т 07 & göstermek & zeigen \\
\hline Т 08 & erken & früh \\
\hline Т 09 & koltuk değneği & Krücke \\
\hline Т 10 & yumuşak & weich \\
\hline Т 11 & tahil & Getreide \\
\hline Т 12 & otomat & Automat \\
\hline Т 13 & raydan çıkmak & entgleisen \\
\hline Т 14 & vahşi & wild \\
\hline Т 15 & bitkiler & Pflanzen \\
\hline Т 16 & conteynir & Container \\
\hline Т 17 & hokkabazlık etmek & jonglieren \\
\hline Т 18 & kozmetik & Kosmetika \\
\hline Т 19 & soymak & schälen \\
\hline Т 20 & bulutsuz & wolkenlos \\
\hline Т 21 & yolcu eşyası & Gepäck \\
\hline Т 22 & itmek & schieben \\
\hline Т 23 & kolay & einfach \\
\hline Т 24 & baharatlar & Gewürze \\
\hline Т 25 & piramit & Pyramide \\
\hline Т 26 & dengelemek & balancieren \\
\hline Т 27 & badminton & Federball \\
\hline Т 28 & beklemek & warten \\
\hline Т 29 & düz & glatt \\
\hline Т 30 & enstruman & Instrumente \\
\hline Т 31 & gösteri yapmak & demonstrieren \\
\hline Т 32 & renksiz & einfarbig \\
\hline Т 33 & kurulamak & abtrocknen \\
\hline Т 34 & cesur & mutig \\
\hline Т 35 & başlık & Kopfbedeckungen \\
\hline Т 36 & tanıd1k & vertraut \\
\hline Т 37 & kap kacak & Geschirr \\
\hline Т 38 & pusula & Kompass \\
\hline Т 39 & spor çeşitleri & Sportarten \\
\hline $\mathrm{T} 40$ & dirsek & Ellenbogen \\
\hline $\mathrm{T} 41$ & mutfak aletileri & Küchengeräte \\
\hline Т 42 & üzgün & traurig \\
\hline Т 43 & şenlik & Feste \\
\hline Т 44 & mücevherat & Schmuck \\
\hline Т 45 & parmaklık & Geländer \\
\hline Т 46 & k1rmak & abbrechen \\
\hline Т 47 & yakin & nah \\
\hline Т 48 & alet & Werkzeuge \\
\hline Т 49 & solmak & verblühen \\
\hline Т 50 & uydu & Satellit \\
\hline Т 51 & orkestra & Orchester \\
\hline Т 52 & sıkıc1 & langweilig \\
\hline Т 53 & tomurcuk & Knospe \\
\hline Т 54 & sofra takımı & Besteck \\
\hline Т 55 & topuk & Ferse \\
\hline Т 56 & dalgalanmak & wehen \\
\hline Т 57 & palto & Mantel \\
\hline Т 58 & yüksek & hoch \\
\hline Т 59 & iş makinaları & Baufahrzeuge \\
\hline Т 60 & vantilatör & Ventilator \\
\hline Т 61 & tartmak & wiegen \\
\hline Т 62 & yiyecekler & Lebensmittel \\
\hline Т 63 & orkestrayı yönetmek & dirigieren \\
\hline Т 64 & duvak & Schleier \\
\hline
\end{tabular}




\begin{tabular}{lll} 
T 65 & sürgü & Riegel \\
T 66 & iceride & innen \\
T 67 & mevsim & Jahreszeiten \\
T 68 & meşale & Fackel \\
T 69 & teselli etmek & trösten \\
T 70 & böcekler & Insekten \\
T 71 & mobilya & Möbel \\
T 72 & çirkin & hässlich \\
T 73 & arma & Wappen \\
T 74 & ekşi & sauer \\
T 75 & bina & Gebäude \\
T 76 & biçak ağz1 & Klinge \\
T 77 & eğilmek & verbeugen \\
T 78 & işaret & Zeichen \\
T 79 & ökçe & Absatz \\
T 80 & rendelemek & reiben \\
T 81 & memnunsuz & unzufrieden \\
T 82 & bilezik & Armreif \\
T 83 & çekmek & ziehen \\
T 84 & sivri & spitz \\
T 85 & azarlamak & schimpfen \\
T 86 & modasi geçmiş & altmodisch \\
T 87 & meslekler & Berufe \\
T 88 & toka & Schnalle \\
T 89 & çekmek & abschleppen \\
T 90 & kuru & trocken \\
T 91 & örmek & stricken \\
T 92 & sap & Henkel \\
T 93 & tehlikesiz & ungefährlich \\
T 94 & bağırmak & brüllen \\
T 95 & tepe & Gipfel \\
& & \\
\hline & &
\end{tabular}

